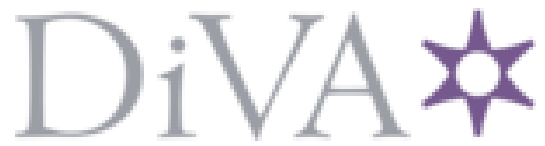

http://www.diva-portal.org

This is the published version of a paper presented at 2016 ASIS\&T Annual Meeting, Oct 14-18, Copenhagen.

Citation for the original published paper:

Enwald, H., Kangas, M., Keränen, N., Korpelainen, R., Huvila, I. et al. (2016)

Opinions and use of mobile information technology among older people in Northern Finland: Preliminary results of a population based study

In: Proceedings of the 2016 ASIS\&T Annual Meeting, Oct 14-18, Copenhagen WileyBlackwell

https://doi.org/10.1002/pra2.2016.14505301119

N.B. When citing this work, cite the original published paper.

Permanent link to this version:

http://urn.kb.se/resolve?urn=urn:nbn:se:uu:diva-332501 


\section{Opinions and use of mobile information technology among older people in Northern Finland - Preliminary results of a population based study}

\author{
Heidi Enwald \\ Information and Communication Studies, \\ University of Oulu \& Information Studies, Åbo \\ Akademi \\ Information Studies, Faculty of Humanities, \\ P.O.Box 8000, FI 90014 University of Oulu, \\ Finland \\ heidi.enwald@oulu.fi \\ Niina Keränen \\ Medical Imaging, Physics and Technology, \\ University of Oulu \\ Medical Imaging, Physics and Technology, \\ P.O.Box 8000, FI 90014 University of Oulu, \\ Finland \\ niina.s.keranen@oulu.fi
}

\section{Isto Huvila}

Information Studies, Åbo Akademi \& Information

Studies, Uppsala University

Information Studies, Åbo Akademi, Fänriksgatan

3B, 20500 Åbo, Finland

isto.huvila@abo.fi

\section{ABSTRACT}

Older people's usage of mobile devices is increasing. This study is part of the GASEL project and seeks to increase the understanding of the use of mobile information technology and opinions towards it. Opinions are compared between genders and age groups. The population based data were collected by conducting a questionnaire survey. A random sample of 1,500 adults 65 years of age or older was obtained from the Finnish Population Register Centre. The number of respondents was 918 with a response rate of 61.2 $\%$. About one fifth $(n=169)$ had used a tablet computer and

\{This is the space reserved for copyright notices.]

ASIST 2016, October 14-18, 2016, Copenhagen, Denmark.

[Author Retains Copyright. Insert personal or institutional copyright notice here.]
Maarit Kangas

Medical Imaging, Physics and Technology, University of Oulu

Medical Imaging, Physics and Technology, P.O.Box 8000, FI 90014 University of Oulu, Finland maarit.kangas@oulu.fi

\section{Raija Korpelainen}

Oulu Deaconess Institute, Department of Sports and Exercise Medicine \& Centre for Life Course Epidemiology and Systems Medicine, University of Oulu

Oulu Deaconess Institute, Albertinkatu 18A, 90100 Oulu, Finland

raija.korpelainen@odl.fi

\section{Timo Jämsä}

Medical Imaging, Physics and Technology, University of Oulu

Medical Imaging, Physics and Technology, P.O.Box 8000, FI 90014 University of Oulu, Finland timo.jamsa@oulu.fi

approximately one third $(\mathrm{n}=226)$ had used a mobile phone with a touch screen in the past 12 months without encountering major difficulties. The respondents had mostly thought that using the devices would not be easy. They had also thought that the usage would not be too expensive for them. Men and younger old people held more positive opinions towards these new technologies. Older people are slower in adapting and accepting new technologies and this should be taken into account when designing services, applications and content, as these technologies have the potential to enrichen the lives of this specific population group.

\section{Keywords}

mobile information technology, smartphone, attitudes, aging, information society

\section{INTRODUCTION AND BACKGROUND}

In Finland, 69 percent of people aged 65 to 74 , and 31 percent of those aged 75 to 89 , had used the Internet in the 
past three months in 2015. For example, 19 percent of those aged 65 to 74 and five percent of 75 to 89 -year-olds had used some form of social network service in a three-month period (Statistics Finland, 2015). Among Icelanders the frequency of information seeking among older people on the Internet increased from 2002 to 2012 (Pálsdóttir, 2015) and this has probably also been the tendency in other countries, including Finland. Generally speaking, the active use of information has been associated with successful aging (Asla, Williamson and Mills, 2006; Asla 2013; Niemelä et al., 2012).

Mobile phones, smart phones and tablets (such as iPads) are becoming more popular all the time. In Finland a tablet was in use in 42 percent of all households in 2015. Respectively, 69 percent of Finns used a smartphone (Statistics Finland, 2015). Older people have often been slow to adopt new technologies, but also their usage of these wireless devices is increasing (Pew Research Center, 2014). As many services, ranging from healthcare to entertainment, go online, seniors also have opportunities to benefit from mobile applications.

However, not all older people are eager to adopt these new devices, or perceive a need for them. Barriers that can affect mobile device use in this population can relate to changes in individuals' sensory, motor or cognitive performance (Fletcher \& Jensen, 2015). The aging process not only involves physical changes, but also psychological and social effects (Wrzus et al., 2013). In the worst case scenario, this could lead to exclusion from society. For instance, Mervyn \& Allen (2012) have investigated the influence of mobile information technology on reducing social exclusion. Furthermore, mobile information technologies can serve as a tool for disempowering or empowering older people. For instance, the findings of Hill, Betts \& Gardner (2015) support evidence of a "grey" digital divide. The use of mobile information technology may allow older people to be more independent and to maintain their social networks, for instance, by keeping in contact with family and grandchildren (Kurniawan, 2008). Social media can also be a form of online information (Narayan et al., 2013).

Psychological factors, such as individuals' beliefs about technology and the perception of need in determining the adoption of new technology have been highlighted in a number of theories, for instance, in the Diffusion of Innovations theory (Rogers 2003) and Theory of Acceptance and Use of Technology (UTAUT) (Venkatesh et al., 2003). According to Fausset et al. (2013, 52), "Understanding older people's perceptions and use of technology is imperative in designing technology and creating successful user-technology interactions." However, studies on the opinions and use of mobile information technology among older people are still rare.

This study contributes to the research into the use of new technologies among older people and the opinions they hold towards it. We present preliminary results of our study which is part of a larger project looking at gamified services for the elderly (the GASEL project).

The research questions were as follows:

1) Have older people used mobile information technology?

2) What kinds of opinions do older people have towards mobile information technology?

a) Are there differences in the opinions of older people towards the use of mobile information technology between the genders?

b) Are there differences between age groups (6569 years old, $70-79$ years old, 80 or older) in the opinions towards the use of mobile information technology?

\section{METHODS AND DATA COLLECTION}

This study was part of a multidisciplinary, population based GASEL project, which was carried out in Finland from 2014 to 2016. In the project a gamified, tailored remote service concept for promoting the health and wellbeing of older people was designed. The study protocol of the project was approved by the Ethics Committee of Human Sciences at the University of Oulu (statement 6/2014).

The study population of the GASEL project consisted of a random sample of 1,500 older adults obtained from the Finnish Population Register Centre. The selected sample were aged 65 or more by the end of 2014, spoke Finnish as a native language, and had a permanent address in the Finnish city of Oulu. The participants received a paper questionnaire by mail at the beginning of November 2014 . A reminder and another copy of the questionnaire were sent to the non-responders four weeks after this. Respondents were offered the opportunity to answer and return the questionnaire either online or on paper. The questionnaire included questions relating to their health status, physical activity, health information seeking behaviour, Internet use and gaming.

The total response rate was $61.2 \%(\mathrm{n}=918)$. The mean age of the final study population was 73.4 (SD 6.8) years and $57.5 \%$ were females. The respondents and non-respondents did not differ according to gender (Pearson's $\chi^{2}$ test $\mathrm{p}=0.418$ ) but there was a statistically significant difference regarding age because the mean age of the non-respondents was 74.9 and 73.4 for the respondents (Mann-Whitney U $\mathrm{p}=0.005)$.

\section{Survey questions}

This study focuses on older people's readiness to use mobile information technology. The questionnaire contained questions relating to the use of mobile devices and on opinions related to the use of these kinds of devices. Factors affecting the adoption of mobile technologies, such as smartphones or tablets included in the UTAUT 
technology acceptance model (Venkatesh et al., 2003) were used as a support in formulating the questions. The participants were asked whether in the last 12 months they had used a tablet computer, or a mobile phone with a touch screen, and whether they had ever used the Internet with a mobile phone. The response alternatives were: "Yes, and there were no major difficulties," as well as, "Yes, but it was difficult to do," in addition to, "No," and, "I don't know."

The participants were instructed as follows: "Give your opinions on the following statements, which are related to the use of mobile information technology devices, such as smartphones or tablets." The response alternatives were: "Yes," and, "No," as well as, "I don't know." The statements were as follows: a) "I am interested in using mobile information technologies", b) "I believe that using mobile information technology is/would be useful in my daily life", c) "I believe that using mobile information technology is/would be necessary in my daily life", d) "Using mobile information technology is easy for me" and e) "Using mobile information technology is too expensive for me".

\section{Data analysis}

The data were analysed using the software package SPSS (version 21 for Windows). Descriptive analyses were done using percentages for categorical variables.

The five statements relating to opinions on the use of mobile devices were further analysed by forming a sum variable from them. The sum variable reflected a positive opinion towards mobile information technology. For the sum variable the statements a)-d) were rated by giving one point for a "yes" response and zero points from other responses. Statement e) was treated differently by giving one point for a "no" response and zero for the others. The point scale was from 0 to 5 wherein 0 reflected the most negative and 5 the most positive opinion towards mobile information technology.

The sum variable was investigated in relation to gender and age. For statistical analysis, the respondents were divided into three age groups: 65-69 years, 70-79 years and 80 years or over. The statistical significance of the associations between the categorical explanatory and response variables were analysed using cross-tabulation with Pearson's chisquared test.

\section{RESULTS}

Over one fifth ( $\mathrm{p}=169,22.5 \%)$ had used tablet computer in the last 12 months and had not had major difficulties. The percentage of the users of mobile phones with touch screen was higher as $29.4 \%(n=226)$ had used them without major difficulties. One fifth $(n=171,20.8 \%)$ had also used the Internet with a mobile phone. Only a few of those who responded "yes" to the questions had encountered difficulties in using mobile devices (see Table 1).

\begin{tabular}{|c|c|c|c|c|}
\hline & $\begin{array}{l}\text { Yes, and } \\
\text { there } \\
\text { were no } \\
\text { major } \\
\text { difficultie } \\
\text { s, N (\%) }\end{array}$ & $\begin{array}{l}\text { Yes, but } \\
\text { it was } \\
\text { difficult to } \\
\text { do, } \\
\mathrm{N}(\%)\end{array}$ & $\begin{array}{l}\text { No, } \\
\text { N (\%) }\end{array}$ & $\begin{array}{l}\text { I don't } \\
\text { know, } \\
\mathrm{N}(\%)\end{array}$ \\
\hline $\begin{array}{l}\text { Have you } \\
\text { used a tablet } \\
\text { computer in } \\
\text { the last } 12 \\
\text { months? }\end{array}$ & $\begin{array}{l}169 \\
(22.5)\end{array}$ & $19(2.5)$ & $\begin{array}{l}538 \\
(71.6)\end{array}$ & $\begin{array}{l}25 \\
(3.3)\end{array}$ \\
\hline $\begin{array}{l}\text { Have you } \\
\text { used a } \\
\text { mobile } \\
\text { phone with a } \\
\text { touch screen } \\
\text { in the last } 12 \\
\text { months? }\end{array}$ & $\begin{array}{l}226 \\
(29.4)\end{array}$ & 12 (1.6) & $\begin{array}{l}485 \\
(63.1)\end{array}$ & $\begin{array}{l}46 \\
(6)\end{array}$ \\
\hline $\begin{array}{l}\text { Have you } \\
\text { ever used } \\
\text { the Internet } \\
\text { with a mobile } \\
\text { phone? }\end{array}$ & $\begin{array}{l}165 \\
(20.1)\end{array}$ & $\begin{array}{l}6 \\
(0.7)\end{array}$ & $\begin{array}{l}638 \\
(77.6)\end{array}$ & $\begin{array}{l}13 \\
(1.6)\end{array}$ \\
\hline
\end{tabular}

Table 1. Usage of mobile information technology among older people.

Opinions relating to the use of mobile information technology could roughly be divided into two categories, positive opinions and negative opinions. Of the respondents, $345(42.9 \%)$ were interested in using mobile information technology, 310 (39.5\%) believed that using mobile devices is or would be useful, and 270 (34.3\%) felt that the usage of mobile technology was necessary for them in their daily lives. One fourth, $(p=296,26.2 \%)$ thought that using mobile information technology was easy for them. However, $144(18.8 \%)$ felt that the use of this kind of technology was too expensive for them (see Table 2). 


\begin{tabular}{|c|c|c|c|}
\hline & $\begin{array}{l}\text { Yes, } \\
\text { N (\%) }\end{array}$ & $\begin{array}{l}\text { No, } \\
\text { N (\%) }\end{array}$ & $\begin{array}{l}\text { I don't } \\
\text { know, } \\
\mathrm{N}(\%)\end{array}$ \\
\hline $\begin{array}{l}\text { I am interested in } \\
\text { using mobile } \\
\text { information } \\
\text { technology }\end{array}$ & $\begin{array}{l}345 \\
(42.9)\end{array}$ & $\begin{array}{l}362 \\
(45.0)\end{array}$ & $\begin{array}{l}97 \\
(12.1)\end{array}$ \\
\hline $\begin{array}{l}\text { I believe that using } \\
\text { mobile information } \\
\text { technology is/would } \\
\text { be useful in my daily } \\
\text { life. }\end{array}$ & $\begin{array}{l}310 \\
(39.5)\end{array}$ & $\begin{array}{l}297 \\
(37.9)\end{array}$ & $\begin{array}{l}177 \\
(22.6)\end{array}$ \\
\hline $\begin{array}{l}\text { I believe that using } \\
\text { mobile information } \\
\text { technology is/would } \\
\text { be necessary in my } \\
\text { daily life. }\end{array}$ & $\begin{array}{l}270 \\
(34.3)\end{array}$ & \begin{tabular}{|l|}
329 \\
$(41.8)$
\end{tabular} & $\begin{array}{l}188 \\
(23.9)\end{array}$ \\
\hline $\begin{array}{l}\text { Using mobile } \\
\text { information } \\
\text { technology is easy for } \\
\text { me. }\end{array}$ & $\begin{array}{l}296 \\
(26.2)\end{array}$ & $\begin{array}{l}345 \\
(43.9)\end{array}$ & $\begin{array}{l}235 \\
(29.9)\end{array}$ \\
\hline $\begin{array}{l}\text { Using mobile } \\
\text { information } \\
\text { technology is too } \\
\text { expensive for me. }\end{array}$ & $\begin{array}{l}144 \\
(18.8)\end{array}$ & $\begin{array}{l}412 \\
(53.9)\end{array}$ & $\begin{array}{l}209 \\
(27.3)\end{array}$ \\
\hline
\end{tabular}

Table 2. Opinions towards mobile information technology among older people.

A sum variable was calculated from the statements relating to the opinions. This variable was then investigated in relation to gender and age.

Men were more positive in their opinions towards mobile information technology (Pearson's Chi square $\mathrm{p}<0.001$ ). (See Figure 1).

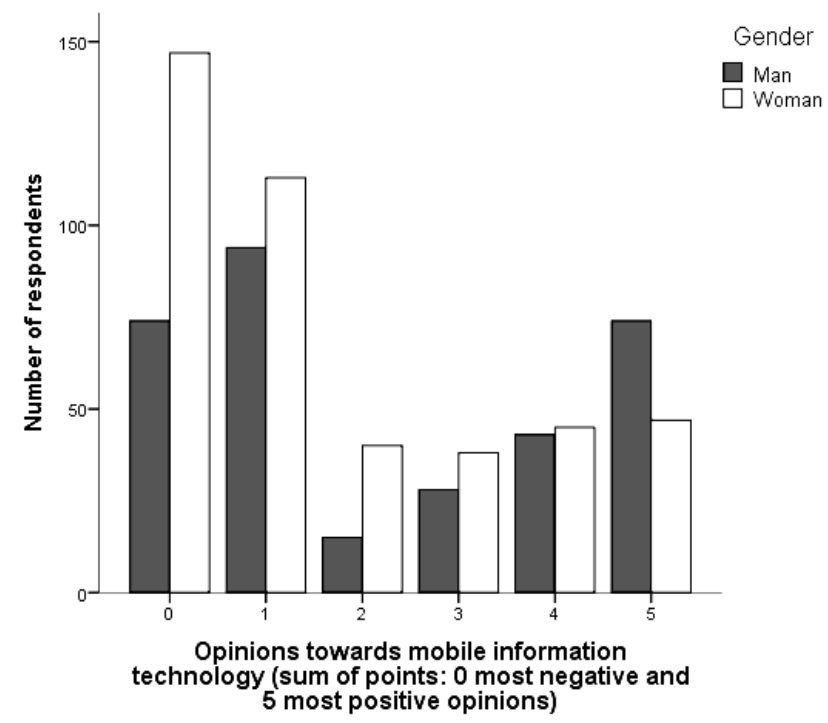

Figure 1. Opinions towards mobile information technology according to gender.

From the study population 38.0\% were 65-69 years old, $41.5 \%$ were $70-79$ years old and $20.5 \%$ were 80 or over. Those under 70 had most positive attitudes towards mobile information technology and those 80 years or over the most negative attitudes (Pearson's Chi square $\mathrm{p}<0.001$ ) (See Figure 2).

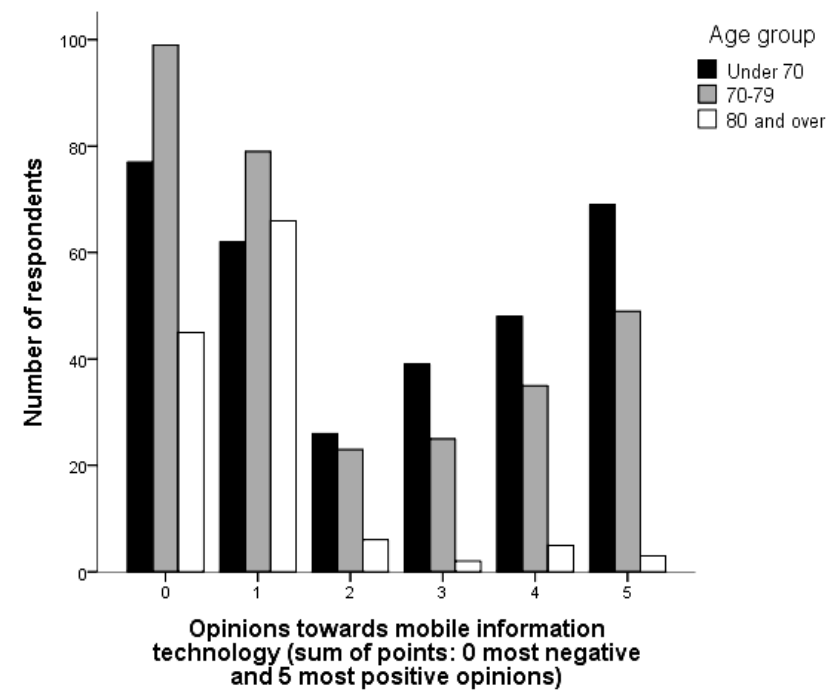

Figure 2. Opinions towards mobile information technology according to age. 


\section{DISCUSSION}

This representative population-based survey study provides new information about older people's use of and opinions towards mobile information technology. Most of the older people in this study who had used tablets or smart phones had not encountered any major difficulties in their use. Opinions relating to the use of mobile information technology divided more or less into two categories; positive and negative. Furthermore, quite many of the respondents were unsure about the topics under examination. Men and those under 70 were the most positive in their opinions towards mobile information technology.

Studies on opinions and the use of new mobile information technology among older people are still rare, but generally speaking, older people may be slower in adaption and acceptance of new technologies. It is important to understand their perceptions and use of technology (Fausset et al., 2013). When designing services, applications and content that is most beneficial when used on mobile devices it should be remembered that not all older people see the value of the use and some are not interested in these kinds of new technologies. However, the designers should also keep this population group in mind and tailor elderlyfriendly services for them.

The work started at multidisciplinary GASEL-project will be continued from the viewpoint of Information Studies under the HIBA project (Taking Health Information Behaviour into Account: implications of a neglected element for successful implementation of consumer health technologies on older adults).

\section{Acknowledgements}

This study was carried out as part of the GASEL project, funded by the Finnish Funding Agency for Innovation (grant no. 40270/13), BelleGames Oy, BonWell Intelligence Oy, the Caritas Foundation, Iscom Oy, Mawell Oy, Northern Ostrobothnia Hospital District, Luleå University of Technology, and Oulu Deaconess Institute.

\section{References}

Asla, T. (2013). The Fourth Age: human information behavior and successful aging. Unpublished doctoral dissertation, Charles Sturt University, NSW, Australia. Retrieved June 4, 2016 from http://www.openthesis.org/documents/Fourth-AgeHuman-Information-Behavior-601676.html

Asla, T., Williamson, K., \& Mills, J. (2006). The role of information in successful aging: The case for aresearch focus on the oldest old. Library \& Information Science Research, 28(1), 49-63.

Fausset, C.B., Harvey, L., Farmer, S., \& Fain, B. (2013). Older adults' perceptions and use of technology:
A novel approach. In C. Stephanidis, M. Antona (Eds.) Universal Access in Human-Computer Interaction. User and Context Diversity. Lecture Notes in Computer Science 8010. (pp. 51-58). Berlin: Springer.

Hill, R., Betts, L.R., \& Gardner, S.E. (2015). Older adults experiences and perceptions of digital technology: (Dis)empowerment, wellbeing, and inclusion. Computers in Human Behavior, 48(Issue C), 415-423.

Kurniawan, S. (2008). Older people and mobile phones: A multi-method investigation, International Journal of Human-Computer Studies, 66, 889-901.

Mervyn, K., \& Allen, D.K. (2012). Sociospatial context and information behavior: Social exclusion and the influence of mobile information technology. Journal of the American Society for Information Science and Technology, 63(6), 1125-1141.

Narayan, B., Talip, B.A., Watson, J. \& Edwards, S. (2013). Social media as online information grounds : a preliminary conceptual framework. Lecture Notes in Computer Science: Digital Libraries: Social Media and Community Networks, 8279, 127-131.

Niemelä, R., Huotari, M.L., \& Kortelainen, T. (2012). Enactment and use of information and the media among older adults. Library and Information Science Research, 34(3), 212-219.

Pálsdóttir, Á. (2015). Senior citizens, media and information literacy and health information. In $\mathrm{S}$. Kurbanoglu, J. Boustany, S. Spiranec, E. Grassian, D. Mizrachi \& L. Roy (Eds.), Information Literacy: Moving Towards Sustainability: Third European Conference, ECIL 2015. Communication in Computer and Information Science, 552. (pp. 233-240). Switzerland: Springer.

Pew Research Center (2014). Older adults and technology use. Retrieved June 5, 2016 from http://www.pewinternet.org/2014/04/03/older-adults-andtechnology-use

Rogers, E. M. (2003). Diffusion of innovations (5th ed.). New York: Free Press.

Statistics Finland (2015). Use of information and communications technology by individuals. Helsinki: Statistics Finland. Retrieved June 8, 2016 from http://www.stat.fi/til/sutivi/2015/sutivi_2015_2015-1126 tie 001 en.html

Venkatesh, V., Morris, M.G., Davis, G.B. \& Davis, F.D. (2003). User acceptance of information technology: Toward a unified view. MIS Quarterly, 27(3), 425-478.

Wrzus, C., Hänel, M., Wagner, J. \& Neyer, F.J. (2013). Social network changes and life events across the life span: a meta-analysis. Psychological Bulletin, 139(1), 5380 . 